\title{
The concept of health and the difference between prevention and promotion
}

\author{
O conceito de saúde e a diferença \\ entre prevenção e promoção
}

Dina Czeresnia 1

\footnotetext{
${ }^{1}$ Departamento de Epidemiologia e Métodos Quantitativos em Saúde, Escola Nacional de Saúde Pública, Fundação Oswaldo Cruz. Rua Leopoldo Bulhões 1480, Rio de Janeiro, $R J$ 21045-900, Brasil. dina@ensp.fiocruz.br
}

\begin{abstract}
In this article the author presents a point of view which she considers central to understanding the difference between prevention - associated with the traditional discourse of public health - and health promotion, an idea in connection with which proposals are now being presented for rethinking and redirecting public health practices. This perspective relates to the limits of the health and disease concepts in relation to the concrete experiences of health and illness. On the one hand, practical awareness of this limit implies far-reaching changes in the way scientific knowledge is related to (and used in) the formulation and organization of health practices; on the other, health promotion projects also avail themselves of the concepts guiding the discourse of prevention. This leads to certain difficulties that appear as inconsistencies or gray areas in the operationalization of promotion projects, which do not always succeed in asserting their nature as distinct from traditional preventive practices.
\end{abstract}

Key words Prevention; Health Promotion; Complexity; Epidemiology

Resumo A autora apresenta uma perspectiva que considera fundamental para a compreensão da diferença entre prevenção - associada ao discurso tradicional da saúde pública - e promoção da saúde, uma idéia dentro da qual propostas estão sendo apresentadas para repensar e redirecionar as práticas em saúde pública. Essa perspectiva tem a ver com os limites dos conceitos da saúde e da doença em relação à experiência concreta das mesmas. Por um lado, a consciência prática desse limite implica em mudanças abrangentes na maneira pela qual o conhecimento científico se relaciona com, é usado para, a formulação e organização das práticas sanitárias; por outro, os projetos de promoção da saúde também lançam mão dos conceitos orientadores do discurso preventivista. Isso leva a certas dificuldades que aparecem como inconsistências ou áreas nebulosas na operacionalização dos projetos de promoção, que nem sempre conseguem se diferenciar das práticas preventivas tradicionais.

Palavras-chave Prevenção; Promoção da Saúde; Complexidade; Epidemiologia 


\section{Introduction}

This paper highlights one of the problems emerging from the very framing of medicine and collective health, with new relevance today in the discussion that seeks to differentiate between the concept of prevention - associated with the traditional discourse of public health - and that of health promotion - another traditional notion, but currently pivotal to approaches for rethinking and redirecting public health practices (MacLean \& Eakin, 1992). The development of scientific, and particularly medical, rationality brought enormous power to bear on constructing representations of reality, in disregard of one fundamental consideration: the limits of concepts in relation to reality. For health, such limits are those of the health and disease concepts vis-à-vis the actual experiences of health and illness.

Building an awareness of this limit lies at the root of current discursive changes in the health field, highlighting that to reflect on health in all its complexity involves far more than overcoming obstacles internal to scientific production, in order to propose concepts and models that are more inclusive and complex. It is not a matter of proposing a "new" science, but of the need to construct discourses and practices that succeed in establishing a different relationship with all forms of scientific knowledge.

Based on this thinking, I propose a point of view that endeavors to demarcate the difference between prevention and promotion in health. The goal is also to gain a better understanding of some of the difficulties that appear as inconsistencies, contradictions, and gray areas in the operationalization of health promotion projects, which do not always succeed in clearly differentiating themselves from traditional preventive practices.

\section{Health, science, and complexity}

Public health/collective health is defined generically as the field of knowledge and institutionally organized practices aimed at promoting the health of populations (Sabroza, 1994). The knowledge and institutionalization of public health practices are shaped in articulation with medicine. Although going beyond the mere application of scientific knowledge, health practices have been represented as fundamentally scientific technical practices. This representation cannot be considered simply a mistake, but rather an essential aspect of these practices, rooted in the effective utilization of scientific knowledge. Medicine was structured on positive sciences and considered its manner of apprehending its object to be scientific (Mendes-Gonçalves, 1994). The scientific discourse, specialty, and institutional organization of health practices were circumscribed by objective concepts, not of health, but of disease.

The concept of disease was built on a reduction of the human body, based on morphological and functional constants defined by such sciences as anatomy and physiology. "Disease" is conceived as endowed with its own external reality, prior to concrete alterations in the bodies of the sick. The body is thus disconnected from the whole set of relationships that constitute the meaning of its life (MendesGonçalves, 1994), even though medical practice enters into contact with concrete human beings and not just with their organs and functions (Canguilhem, 1978).

One issue is that public health defines itself as responsible for promoting health, while its practices are organized around disease concepts. Another is that its practices tend not to consider the distance between the concept of disease (a mental construct) and falling ill (a lived experience), thus substituting one for the other. Concepts of disease shape specific forms of intervention. The concept of disease is used not only as if it could speak for the concrete fact of falling ill. Most importantly, it produces concrete practices that are represented as able to respond to the latter in its entirety.

Edgar Morin, in O Problema Epistemológico da Complexidade (The Epistemological Problem of Complexity), highlights that a concept cannot adequately replace something far more complex. He relates complexity to the "difficulty of thinking, because thinking is a struggle with and against logic, with and against the concept"; that is, the "difficulty of the word that attempts to grasp the inconceivable and silence" (Morin, s.d.:14). The word, although an elaborated form of expression and communication, is insufficient to grasp reality in its entirety.

Human thinking developed in two directions: towards depth, reduction, and narrowing, and towards breadth, inclusiveness, and extension of frontiers. Modern scientific thinking tends towards reduction, taking up the challenge of attaining maximum precision and objectivity by translating events into abstract, calculable, and demonstrable schemata. The language of mathematics is deemed capable of expressing the universal laws governing phenomena. The elements of events that words - 
or, more precisely, scientific concepts - have been unable to encompass tend to be considered errors or anomalies. The objective word's meaning has been presented in lieu of the thing itself, the sensible aspect of which has been considered non-existent.

Reference to occurrences in their entirety highlights the mutilating aspect of knowledge, an issue raised ever since this way of grasping reality came into being. In the contemporary world, the problem has certainly become more explicit as a result of impasses generated by progressive fragmentation of knowledge. The need to integrate the parts has arisen within analytical logic. How can information and knowledge be integrated when they have been constructed in a quest for increasing depth?

Scientific thinking was presented with the challenge of striving for breadth, of valuing an understanding of interaction among parts, towards unity and totality. The question of complexity emerged in scientific discussion as the possibility of explaining reality or living systems through models seeking not only to describe elements of objects, but particularly the relations established among them. It became evident that there were different levels of organization in reality, each with its own emerging qualities. However, this endeavor found its limit in the fact that reality is unspeakable, pointing to how the construction of any model is inevitably reductive.

Health and falling ill are ways by which life manifests itself. They are unique, subjective experiences; words cannot recognize and signify them entirely. Yet the sick use words to express their illness. Physicians also use words to give meaning to their patients' complaints. In the relationship among the concrete event of falling ill, the patient's words, and those of the health professional, tension arises that leads back to our main question: the tension between the subjectivity of illness and the objectivity of concepts assigning meaning and proposing interventions to deal with that experience.

Complaints and symptoms reported by the ill, loaded with emotion, are translated into neutral, objective language. The shortcomings of medical text in reflecting this broader dimension of human suffering drew medicine closer to literature. Through literature, countless physicians were able to express human suffering beyond the limits of the objectivity of scientific discourse. Writers like Thomas Mann and Tolstoy described the human condition in relation to illness and death as few others have succeeded. This same theme is developed by another physician-writer, Moacyr Scliar, in his book A Paixão Transformada (Passion Transformed), showing how fiction is revealing "because it speaks of the hidden aspect of medicine and illness" (Scliar, 1996).

Scientific medical discourse does not contemplate the broader signification of health and falling ill. Health is not an object that can be constrained within the field of objective knowledge. It does not translate into scientific concept. The same goes for the suffering that characterizes illness. Even Descartes, considered the first to formulate the mechanistic concept of the body, recognized that certain parts of the living human body are accessible exclusively to the owner (Caponi, 1997). This aspect was considered and analyzed in depth by Canguilhem (1978) in Le Normal et le Pathologique. In a more recent study, this author affirms the concept of health as vulgar - having to do with each of our lives - and a philosophical issue, distinguishing it from a scientific concept (Canguilhem, 1990).

Nietzsche, for whose philosophy vital things provide a basic point of view, states the following in relation to medicine and philosophy, revealing the breadth of all that is evoked by the term health: "I am still waiting for a philosophical doctor, in the exceptional sense of the word - a doctor who looks after the overall health of people, time, race, humanity - who will even once have the spirit to take my suspicion to the limit and venture the proposition: all of philosophizing to this day has not dealt with 'truth' but with something else; call it health, future, growth, potency, life..." (Nietzsche, 1983:190).

What does this approximation among medicine, literature, and philosophy show if not evidence that, as Edgar Morin pointed out, objectivity cannot exclude the human spirit, the individual subject, culture, society? Medicine was also considered an art. However, throughout its historical development it has hegemonically tended to identify with a belief in the omnipotence of technique based on science. The gap between the singular experience of health and illness and the opportunities for knowledge of that experience have not been properly recognized. This has led to a major problem in historically shaping the use of scientific concepts to instrumentalize health practices. Scientific truth predominated almost exclusively in representations of both reality and (most importantly) health practices.

Unlike literature, scientific thought mistrusts the senses. In developing a scientific concept, immediate contact with reality appears as a confused, provisional datum requiring a rational effort of discrimination and classifica- 
tion (Bachelard, 1983). Displaced from the senses, scientific explanation constructs propositions guided by planes of reference outlining and confronting whatever is indefinite and inexplicable (Deleuze \& Guattari, 1993). Scientific construction cannot escape the need for a circumscribed plane of reference. Within these limits, explanation becomes possible by creating operative resources to deal with reality. To accept the limited domain of scientific thought thus qualifies its relevance, besides establishing a restriction, since this limit is illusory, and no objective explanation can deny the existence of mysterious, inexplicable, or unsayable things.

The issue is that the discourse of modernity has not taken this restriction into account. Considering the limit on scientific construction and its inevitably reductive character, one can say that no concept, or system of concepts, can expect to account for the unity characteristic of singularity. Concepts express identities, while the singular unit is an expression of difference. However much explanatory potential a concept may have and however operative it may be, it is unable to express the phenomenon in its entirety; that is, it cannot represent reality. When one constructs a coherent, logical explanatory system of explanation, one encloses reality in a reduction. One can thus concede that to accept this mental construct as capable of replacing reality mutilates the possibilities for grasping reality via the senses.

The point is not to question scientific thought as limited and reductive, but rather to criticize the point of view that denies the limits on scientific construction. This denial is expressed, on the one hand, when scientific truth is taken as dogma and becomes insensitive to what is inexplicable, to what has not been rendered into concepts. It also occurs when science is required to account for what is not proper to it. No science can account for singularity, no matter how many new complex models are constructed to explain reality. Attempts to account for singularity establish new relations between whatever knowledge is constructed through concepts and models and the singular occurrence it is intended to explain. The emphasis here is the need to reassess the limits on science in order to revalue and broaden interaction with other legitimate ways of grasping reality.

As we have seen, philosophy and literature have always been complementary to medicine, albeit marginally. When the primacy of scientific objectivity is questioned today, it cannot be to propose imploding these frontiers to con- struct a unifying discourse. What is reaffirmed is the need to revalue approximation - in action - among essentially different forms of language, enabling them to complement one another. The issue is to consider the truth value of scientific concepts in a relative light - to make use of them, but not to believe in them absolutely - thus opening up channels for valorizing the relationship between sensibility and thought, without relinquishing our understanding of scientific knowledge, reinstating the importance of the role of philosophy, art, and politics. The effort is to build a new relationship with the truth that will permit "wisdom to be found through and beyond knowledge" (Atlan, 1991:18).

It is not by discovering some novelty, but by renewing the issues that modernity and enlightenment thought were smothered. While continuing to use scientific knowledge and seeking to extend the possibilities of existing models, we cannot block the channels that make us sensitive to reality. What we need is to recover old philosophies that have been forgotten and sidelined by disproportionate belief in reason and man's power to control and dominate. The aim is not truth, but happiness, wisdom, and virtue (Atlan, 1991). Health also, and medicine itself, are concerned - as asserted in the above quote from Nietzsche - not with "truth", but with “... future, growth, potency, and life".

This issue is structural to the field of public health and lies at the root of what we call its "crisis". This aspect is fundamental in order to situate ourselves in the context of contemporary changes in public health discourse and, from the standpoint of this article, to properly understand what differentiates prevention and promotion in health. The discursive transformations are not only internal to the logic of scientific discourse, but most importantly they redefine the limits and meanings of knowledge produced in shaping health practices and consequently in the formulation of training programs for health professionals. The proposal is for a new way of using scientific rationality to explain reality and, chiefly, to act. This process entails more radical transformations than a change within science, as they have to do with building a world view capable of interfering in the enormous power that scientific rationality wields in constructing representations of reality. 
Public health and the difference between prevention and promotion

To prevent means "to forestall or thwart by previous or precautionary measures; provide beforehand against the occurrence of (something); make impracticable or impossible by anticipatory action; stop from happening" (New Shorter Oxford English Dictionary - Oxford University Press, 1997). Prevention in health, according to the classic work by Leavell \& Clarck (1976:17), "calls for action in advance, based on knowledge of natural history in order to make it improbable that the disease will progress subsequently". Preventive actions are defined as interventions directed to averting the emergence of specific diseases, reducing their incidence and prevalence in populations. The discourse of prevention is based on modern epidemiological knowledge. It aims to control the transmission of infectious diseases and reduce the risk of degenerative diseases or other specific ailments. Health prevention and education projects are structured by circulation of scientific knowledge and normative recommendations to change habits.

To promote means "to further the development, progress, or establishment of (a thing); encourage, help forward, or support actively ( $a$ cause, process, etc.)" (New Shorter Oxford English Dictionary - Oxford University Press, 1997). Traditionally, health promotion is defined more broadly than prevention, since it relates to measures that "are not directed to a given disease or disorder, but serve to increase overall health and well-being" (Leavell \& Clarck, 1976: 19). Promotion strategies emphasize changing the conditions of people's lives and work, which form the structure underlying health problems, calling for an inter-sectoral approach (Terris, 1990).

Realization that the main determinants of health are external to the treatment system is not new. However, official formulation of public health discourse to positively affirm health is quite recent. The International Conference on Health Promotion, held in Ottawa (1986), postulated the idea of health as quality of life resulting from a complex process conditional on several factors: diet, social justice, ecosystem, income, education, etc. The broad concept of health came to the fore in Brazil that same year and was incorporated into the $R e$ latório Final da VIII CNS (Final Report of the 8th National Health Conference, 1986 - MS, 1986): "The right to health means the state's guaranteeing decent living conditions and universal and egalitarian access to measures and services for the promotion, protection, and recuperation of health, at all levels, to all inhabitants of Brazilian territory, leading to the full development of the individual human person".

Although this undeniably constitutes progress, this positive concept entailed a new problem at both the theoretical and practical levels. By considering health in its full sense, we are dealing with something as broad as the notion of life itself. Promoting life in all its multiple dimensions involves measures at the overall state level and the singularity and autonomy of individual subjects, which cannot be made the responsibility of an area of knowledge and practices.

This official recognition of the medicinebased public health model's limits, given that it should be integrated with environmental, social, political, economic, and behavioral dimensions, as well as with biology and medicine, is an undeniable milestone (Carvalho, 1996). Measures proper to health systems should certainly be articulated with other sectors of disciplines and government policy responsible for the physical, social, and symbolic dimensions. However, this relationship between inter-sectorality and specificity is a problematic field that must be trodden with care, because there is enduring tension between defining the limits between the specific competence of measures in the health field and the necessary openness to integration with various other disciplines. If specificity is not achieved by a discipline, it must be based on delimitation of the problems, making it possible to implement effective practices.

In the context of implementing health practices, there is ongoing tension between two definitions of life: first, as our subjective experience, and second, as the object of life sciences, studying physical and chemical mechanisms structuring the cognitive foundation for interventions by medicine and public health. Objective, operational health care interventions were formulated on the basis of concepts and theories concerning biological or psychological specifics. Any theory is reductive and incapable of accounting for all health and illness phenomena. In conceiving of the subject's unity, the most one can aspire to is to express it as "bio-psycho-social integration", continuing to make itself manifest in a fragmented manner by way of concepts that do not easily converse with each other. While living matter is more complex than the concepts that endeavor to explain it, operative interventions are made possible through concepts. There is no way of producing alternative forms of health care that 
do not seek to operationalize concepts of health and disease.

This demarcation applies not only to the constraints on specific health care action (i.e., social conditioning factors in the inter-sectoral dimension), but also to the limits of the objective concepts shaping the logic of interventions (i.e., singularity and subjectivity in the concrete fact of falling ill). In this sense, Canguilhem highlights the recognition that the necessary concern with the subjective body should not lead to any obligation towards liberation from the tutelage of medicine, which is held to be repressive. "Recognition of health as the body's truth, in the ontological sense, can and should admit the presence, as both a boundary and barrier, of truth in the logical sense, i.e., of science. The body lived is certainly not an object; however, for man, living is also knowing" (Canguilhem, 1990:36).

It is doubtless fundamentally important to value and create ways to broaden channels of receptivity to the senses. The point of departure and reference for the experience of health and illness is the body's prime intuition. However, if used without reification, reason mediated by scientific knowledge enables intuition to be broadened and, most importantly, serves as "both an instrument for dialogue and a protective barrier" (Atlan, 1991:13) for the singular experience of falling ill. Scientific knowledge and the operative opportunity of technique in health practices should be used without causing a disconnection from sensitivity in relation to our own bodies. The challenge is to be able to transit between reason and intuition, knowing how to view knowledge in a relative light without ignoring its importance, while broadening the possibility of solving concrete problems.

It is precisely here that the radical - and at the same time very small - difference between prevention and promotion in health stands out. It is radical because it entails far-reaching change in the way knowledge is interlinked and used in formulating and operationalizing health practices, and this can only truly occur by way of a transformed world view, as discussed above. It is very small because the practices of promotion, just like those of prevention, use scientific knowledge. Health promotion projects also rely on the classic concepts disease, transmission, risk - that guide the production of specific knowledge in health and whose rationality is the same as that of prevention discourse. This can lead to confusion and a lack of differentiation between the practices, mainly because the radical difference between prevention and promotion is not always clearly affirmed or exercised.

The idea of promotion involves strengthening individual and collective capacity to deal with the multiplicity of factors that condition health. Promotion goes beyond applying techniques and norms, recognizing that it is not enough to know how diseases function and to find mechanisms to control them. It has to do with strengthening health by building a capacity for choice, using knowledge to discern differences between (and singularities in) events.

In the context of change in traditional public health approaches, the approach by Castellanos (1997) to the concept of health status allows us to broaden our understanding of health promotion as an idea. Health status is defined according to the options of the social actors involved in the process. It cannot be understood "apart from the intentionality of the subject that analyzes and interprets it" (Castellanos, 1997:61). Under the health status concept, health needs are differentiated from health problems. Needs are formulated by objective analyses and procedures. Problems require a more complex approach, shaped by choosing priorities involving the actors' individual and collective subjectivity in their day-to-day activities (Castellanos, 1997).

In the context of change in scientific discourse that surfaced in collective health some ten years ago, there emerged a recognition of values like subjectivity, autonomy, and difference. In understanding health and disease processes, there was an effort to reinterpret the meaning of such concepts as subject and nature (Costa \& Costa, 1990), while calling into question approaches that restricted processes to either the biological dimension or generic and structural determinants (Fleury, 1992).

As discussions advanced within the field, it became clearer that reflecting on health in a complex manner does not mean incorporating a new discourse that migrates from the pole of objectivity to the pole of subjectivity, from the universal to the singular, from the quantitative to the qualitative, etc. It is not simply a question of opting for values that were suppressed during the development of modern scientific rationality, and now to suppress those that formerly were hegemonic. It is thus not an issue of constructing new perspectives that continue to reproduce old oppositions, but to learn how to transit between these different levels and ways of understanding and apprehending reality, taking as a reference not systems of thought, but the events that mobilize us to elaborate and intervene. 
To properly understand how promotion differs from prevention is precisely to be aware that the uncertainty of scientific knowledge is not simply a technical limitation which can be successively overcome. Achieving health is a question not only of survival but of qualifying existence (Santos, 1987). It refers one to the social, existential, and ethical dimension, to a path of its own that refers to concrete situations, to an engagement and active commitment by subjects who devote their uniqueness to placing what is known at the service of what is not known in the search for the truth that emerges in lived experience (Badiou, 1995). Therefore, thinking in terms of health promotion is knowing that changes in behavior are oriented simultaneously by what is known of deterministic conditions and by the clear realization that not all of them are known, nor will they ever be (Atlan, 1991).

Practical awareness of the limits of knowledge means laying no claim to a new scientific theory that can formulate a discourse capable of unifying all the dimensions involved in health. Promoting health involves choice, and this is not really the sphere of knowledge, but of value. It is linked to processes that are not expressed by way of precise, easily measured concepts. Terms like "empowerment" (Eakin \& MacLean, 1992) and "vulnerability" (Ayres et al., 1997) are being developed and used increasingly in the context of health promotion proposals. These "quasi-concepts" not only permit transdisciplinary approaches by linking with concepts from other areas, but they are open to the multiple meanings emerging from the consideration of difference, subjectivity, and singularity in individual and collective health occurrences.

However, this openness continues to take the concepts that shape the specificity of the public health field as a reference for dialogue. This dialogue is not achieved without gaps and gray areas. One example in this respect is the important link between health promotion projects and knowledge developed through epidemiological risk studies. This link occurs in studies that articulate with other multiple approaches (for example, studies on vulnerability to AIDS), which integrate the dimensions of personal behavior, social context, and organization of institutional programs (Mann et al., 1993; Ayres et al., 1997). Many projects that define themselves as promotion also point to occupational and environmental exposure as origins of disease. They propose encouraging such behavioral changes as exercise, use of seat belts, and stopping smoking and use of alcohol and other drugs.

\section{Epidemiology and health promotion}

The integration of epidemiology and health promotion lies in the problematic field analyzed in this article. What has been said about the difference (and similarity) between prevention and promotion also has to do with the use of epidemiological concepts, which are the basis of preventive public health discourse. It is not an issue of "accusing" the reductive aspect of these concepts as a limit to understanding the complexity of health and disease processes in populations or to shaping public health practices. Rather, it is a matter of being clearer about the limits of these concepts, fostering direct attempts to improve methods and to construct new concepts and use them in a more integrated and appropriate way for the interests and needs of structuring health policies for promotion.

Epidemiological knowledge plays an undeniably central role in shaping public health practices. The traditional discourse of prevention suffered from the theoretical poverty and hegemony of mechanistic, linear logic in the conceptual development of epidemiology. Such problems have been revealed by existing critiques of the epidemiological concept of risk (Goldberg, 1990; Almeida-Filho, 1992; Castiel, 1994; Ayres, 1997). What values are produced by representations formed through this concept? What meanings are generated socially when habits and behaviors are identified as risks to health?

The formal aim of risk analysis is to infer causality, to assess the probability of disease events in individuals and/or populations exposed to given factors. Nonetheless, despite proposing to measure individual or collective risks, what the risk model's mathematical method estimates is the "average causal effect" - a reduction from both the individual and collective point of view. Such reductions - logical transitions that are necessary and inevitable if the method is to be workable - construct representations divorced from the complexity of the processes. The problem is that transformations produced through risk studies tend to be used without considering the shifts in logical levels they produce. The strict limits on applying risk estimates are not properly considered, thus "deleting" important aspects of the respective phenomena (Czeresnia \& Albuquerque, 1995).

This "deletion" is not value-free. On the contrary, cultural meanings proliferate in it. The options involved in the process by which something is both revealed and concealed correspond to interests, values, and needs. The de- 
velopment of risk analysis was linked to a cultural process that constructed an individualist Man, faced with the need to deal with the disaggregating forces of nature and society through a logic of order and protection and who invested little in improving relations with others by strengthening his own autonomy (Czeresnia, 1997).

Considering that one of the main aspects in the notion of health promotion is to stimulate autonomy, the challenge that arises involves far-reaching transformations in how one deals with such representations. There can be no proposing "objective, quickly executable recommendations" that will form a capacity to appropriate information without the "risk" of values being incorporated uncritically. Clarity as to the values contained in the different promotion projects is one of the main problematic points in the proposal. Any practice in health promotion presents points of view as to what is "good health". The general idea of promoting health conceals deep-rooted theoretical and philosophical tensions (Seedhouse, 1997). Health promotion proposals are even open to the possibility of broadening practices to incorporate alternative rationalities complementary to the ones characteristic of traditional public health discourse. Diversity is salutary to the extent that its theoretical foundations are made explicit.

It is with this care that one should consider proposals such as that of evidence-based medicine, which use essentially epidemiological criteria and methods to systematize the results of applied research, clinical experiments, and public health (Jenicek, 1997). How is a "best evidence" finding, formulated through clinical epidemiological knowledge, to be related to clinical experience and public health? What are the mediations between operational criteria and practical decisions? How are technical "good recommendations" to be translated into action (Jenicek, 1997)? No technical protocol can solve the implementation of "good practice”, which does not disqualify the relevancy of constructing protocols that optimize information on procedures (quite the contrary). There can be no working properly and practically on constructing the idea of health promotion without facing two fundamental, connected issues: the need for philosophical thinking and the consequent reconfiguration of education (communication) in health practices.

Philosophical discussion is considered crudely as "dilettante", hovering above life and the real world. However, without it there is no way to deal with the gray areas that emerge as we seek to dialogue and flow between the different dimensions in the complexity of health. Without reflection, there is no way to meet the challenge of translating information generated by the production of scientific knowledge into actions that can effectively promote social and environmental change, as well as changes in "unhealthy" behavior by subjects. The emerging challenges are not resolved simply by applying new models; the question of education is not solved merely with information and technical capacity-building.

\section{Acknowledgement}

I wish to thank Antonio Claret Campos Filho for his collaboration.

\section{References}

ALMEIDA-FILHO, N., 1992. A Clínica e a Epidemiologia. Salvador: APCE/Rio de Janeiro: Abrasco.

ATLAN, H., 1991. Tudo, Não, Talvez: Educação e Verdade. Lisbon: Piaget Institute.

AYRES, J. R. M. C., 1997. Sobre o Risco: Para Compreender a Epidemiologia. São Paulo: Editora Hucitec/Rio de Janeiro: Abrasco.

AYRES, J. R. M. C.; FRANÇA Jr., I. \& CALAZANS, G. J., 1997. AIDS, vulnerabilidade e prevenção. In: Seminário Saúde Reprodutiva em Tempos de AIDS, II. Anais, pp. 20-37, Rio de Janeiro: Associação Brasileira Interdisciplinar de AIDS - ABIA.

BACHELARD, G., 1983. Epistemologia. Rio de Janeiro: Zahar.

BADIOU, A., 1995. Ética: Um Ensaio Sobre a Consciência do Mal. Rio de Janeiro: Editora Relume-Dumará. 
CANGUILHEM, G., 1978. O Normal e o Patológico. Rio de Janeiro: Forense-Universitária.

CANGUILHEM, G., 1990. La Santé: Concept Vulgaire e Question Philosophique. Paris: Sables.

CAPONI, S., 1997. Georges Canguilhem y el estatuto epistemológico del concepto de salud. História, Ciências e Saúde: Manguinhos, 4:287-307.

CARVALHO, A. I., 1996. Da saúde pública às políticas saudáveis - Saúde e cidadania na pós-modernidade. Ciência \& Saúde Coletiva, 1:104-121.

CASTELLANOS, P. L., 1997. Epidemiologia, saúde pública, situação de saúde e condições de vida. Considerações conceituais. In: Saúde e Movimento Condições de Vida e Situação de Saúde (R. B. Barata, org.), Rio de Janeiro: Abrasco.

CASTIEL, L. D., 1994. O Buraco e o Avestruz: A Singularidade do Adoecer Humano. Campinas: Papirus.

COSTA, D. C. \& COSTA, N. R., 1990. Teoria do conhecimento e epidemiologia: Um convite à leitura de John Snow. In: Epidemiologia. Teoria e Objeto (D. C. Costa, org.), pp. 167-202, São Paulo: Editora Hucitec/Rio de Janeiro: Abrasco.

CZERESNIA, D. \& ALBUQUERQUE, M. F. M., 1995. Modelos de inferência causal: Análise crítica da utilização da estatística na epidemiologia. Revista de Saúde Pública, 29:415-423.

CZERESNIA, D., 1997. Do Contágio à Transmissão: Ciência e Cultura na Gênese do Conhecimento Epidemiológico. Rio de Janeiro: Editora Fiocruz.

DELEUZE, G. \& GUATTARI, F., 1993. O Que é a Filosofia? Rio de Janeiro: Editora 34.

EAKIN, J. \& MACLEAN, H., 1992. A critical perspective on research and knowledge development in health promotion. Canadian Journal of Public Health, 83:72-76.

FLEURY, S., 1992. Saúde: Coletiva? Questionando a Onipotência do Social. Rio de Janeiro: RelumeDumará.

GOLDBERG, M., 1990. Este obscuro objeto da epidemiologia. In: Epidemiologia. Teoria e Objeto (D. C. Costa, org.), pp. 87-136, São Paulo: Editora Hucitec/Rio de Janeiro: Abrasco.
JENICEK, M., 1997. Epidemiology, evidence-based medicine, and evidence-based public health. Journal of Epidemiology, 7:187-197.

LEAVELL, S. \& CLARCK, E. G., 1976. Medicina Preventiva. São Paulo: McGraw-Hill.

MacLEAN, H. \& EAKIN, J., 1992. Health promotion research methods: Expanding the repertoire. Canadian Journal of Public Health, 83:4-5.

MANN, J.; TARANTOLA, D. J. M. \& NETTER, T. W., 1993. A AIDS no Mundo. Rio de Janeiro: Associação Brasileira Interdisciplinar de AIDS - ABIA/Relume-Dumará.

MENDES-GONÇALVES, R. B., 1994. Tecnologia e Organização Social das Práticas de Saúde: Características Tecnológicas do Processo de Trabalho na Rede Estadual de Centros de Saúde de São Paulo. São Paulo: Editora Hucitec/Rio de Janeiro: Abrasco.

MORIN, E., (s.d.) O Problema Epistemológico da Complexidade. Portugal: Publicações Europa-América.

MS (Ministério da Saúde), 1986. Anais da VIII Conferência Nacional de Saúde. Brasília: MS.

NIETZSCHE, F., 1983. Obras Incompletas. São Paulo: Abril Cultural.

OXFORD UNIVERSITY PRESS, 1997. New Shorter Oxford English Dictionary. Oxford University Press.

SABROZA, P. C., 1994. Saúde Pública: Procurando os Limites da Crise. Rio de Janeiro: Escola Nacional de Saúde Pública, Fundação Oswaldo Cruz. (mimeo.)

SANTOS, B. S., 1987. Um Discurso Sobre as Ciências. Porto: Edições Afrontamento.

SCLIAR, M., 1996. A Paixão Transformada: História da Medicina na Literatura. São Paulo: Companhia das Letras.

SEEDHOUSE, D., 1997. Health Promotion: Philosophy, Prejudice and Practice. England: Willey.

TERRIS, M., 1990. Public health policy for the 1990s. Annual Review of Public Health, 11:39-51. 